\title{
Strategic Framework for Designing E-Government in Developing Countries
}

\author{
Catherine G. Mkude and Maria A. Wimmer \\ Institute for IS Research, University of Koblenz-Landau, \\ Universitätsstr. 1, 56070 Koblenz, Germany \\ \{cmkude, wimmer\} @uni-koblenz.de
}

\begin{abstract}
Developing countries have embarked on e-government initiatives in their modernization activities, as the developed countries. Despite the effort, implementation of e-government in developing countries is still rated as not sufficient. Several literatures, such as the UN 2012 survey, investigate challenges faced by developing countries; poor management and limited availability of resources being the main ones. Developing an e-government system with limited resources and with the challenges developing countries are facing requires careful planning. The ultimate question is the public value generated and the sustainability of e-government initiatives in developing countries. Our main question driving the investigation in this paper is, therefore, whether guidelines exist to develop e-government solutions with the goal of public value generation in mind. The investigations of literature have unveiled many guidelines for designing e-government systems. However, there is still lack of a comprehensive framework that will enable developing countries to design e-government systems whilst generating public value. In this paper, existing guidelines for development of e-government systems are first reviewed followed by a comparison among the guidelines. Then the challenges for designing e-government systems in developing countries are outlined. Through a consolidated view emerging from the comparison and the outlined challenges, the paper brings forth a comprehensive strategic framework for successful design of e-government systems. The proposed framework is for policy makers and egovernment coordinators to design e-government systems in a way that the objectives are met and that the investments generate public value.
\end{abstract}

Keywords: E-Government systems development, E-government design, Guidelines, Developing Countries, Public value.

\section{Introduction}

Governments around the world have been embarking on e-government initiatives for more than 10 years [3] and thus building knowledge societies. The benefits and values of e-government have been recognized more and more among governments. Such benefits include enhanced quality of public services, transparency and accountability, cost-effective service provision and government operation, reduced corruption, citizen 
engagement in public matters, optimization of public policies for better outcomes and integrated government processes [2, 3, 4, 21, 25, 27]. E-government enhances good governance by enforcing good governance principles through implementation. The good governance principles put forward by the OECD are "legitimacy, rule of law, transparency, accountability, integrity, effectiveness, coherence, adaptability, participation and consultation" [22]. Many of these benefits have been highly realized in developed countries as compared to developing countries.

The UN survey of 2012 points out that the efforts for e-government implementation in developing countries such as South Africa, the United Arab Emirates (UAE), China, India, Seychelles and Tuvalu have been considerable since 2010. The survey also reveals that the efforts are insufficient compared to the high achievements in developed countries, and that the main challenges faced in developing countries are poor management and limited availability of resources [31]. Developing an e-government system with numerous challenges and scarce resources requires careful planning [12], especially when most of the funding for development of e-government systems in developing countries depends on donors [13]. Therefore, the ultimate questions are the value-add generated by these systems and the sustainability of such initiatives in developing countries. Considerations in designing e-government systems under afore mentioned conditions require a comprehensive design framework, which still lacks in many guidelines proposed in the literature.

The objective of this paper is to propose a strategic framework for design of e-government systems in developing countries. The framework is based on literature research and comparison of existing frameworks. It bases on two frameworks from the literature [34 and 26] and elaborates them further suggesting five aspects of strategic consideration: vision, policies/strategies, programs, projects and evaluation. Evaluation is crucial to understand generation of public value as well as achievement of vision and subsequent policies/strategies. Key aspects addressed and remainder of this paper are: identification and comparison of existing guidelines for design of e-government systems (sections 2 and 3), challenges for designing e-government systems in developing countries (section 4), consolidation of discussed guidelines in a comprehensive strategic framework (section 5) and finally the lessons that can be learned, best practices and recommendations (section 6). The conclusions in section 7 revisit the objectives of the paper and provide an outlook on further research.

\section{Reviewing Existing Guidelines for Design of E-Government Systems in Developed and Developing Countries}

Many e-government initiatives across countries have been put in place as part of national strategies for economic and societal development. As countries embark further on initiating these strategies, the importance of research in implementing successful e-government is more recognized [35]. Researchers and practitioners around the world have constructed multiple guidelines that countries can adapt in their initiatives. The guidelines for designing e-government systems are of different contexts. In light of understanding the importance of 'country-context' in developing e-government 
systems guidelines [5, 13, 25], some researchers have specified whether the guidelines are constructed in the context of developing countries.

To develop an understanding and consolidated view of different guidelines in the literature, we reviewed existing ones in the contexts of developed and developing countries. This approach enables a wider understanding of guidelines from both contexts and hence provides a richer base for the analysis of the study. The criteria for selection of guidelines were: they must be from the contexts of developed and developing countries respectively, they clearly describe the design of e-government systems, they must be implementation guidelines preferably implemented in case study, and developed in academic research or internationally recognisable organisations. The following nine guidelines were studied (of which six are in the context of developing countries) - see also table 1 for a summary of their main activities proposed:

$\mathrm{EGOV}^{*}$ is a framework for developing e-government systems at national level with the purpose of ensuring sustainability in developing countries. Along with the specified activities, the framework is developed with pillars of key actors namely the government, local stakeholders and external assistance and principles which are: national ownership, strong leadership, stakeholder engagement and balancing internal and external roles [9].

Clockwork suggests a framework consisting of five stages for implementing e-government projects. The author proposes important aspects of consideration along with the framework: environmental complexity in implementing ICT, project prioritizing proportional to public value, employee capacity, and choice of technologies in respect with organizational processes, management and cost underestimation (Clockwork cited in [12]).

Bhatnagar proposes nine guidelines for designing e-government systems at national level in developing countries. The author discusses that e-government implementation comes with diverse goals and objectives such as transparency, efficiency, anti-corruption and effectiveness. Furthermore government reformation requires careful planning along availability of resources and country-context [5].

Rabaiah and Vandijck propose a practice-based strategic framework for egovernment based on modules. The principles of module-based design of the framework are: flexibility, extensibilities and customisability. The framework is developed following a review of strategies in the literature from different countries [23].

E-government transition model is a maturity model that explains step by step transition of government into an electronic government. The authors however argue that the model is not sufficient enough to be an operational model since there is no defined guideline for transformation, citizen engagement and development of web-enabled services [8].

UNESCO e-government action plan is a guideline for stakeholders in developing countries in initiating, developing and sustaining e-government initiatives. The stakeholders addressed in the guideline are parliamentarians, government executives and non-governmental organisations [30].

Republic of Korea's implementation of the UNESCO action plan has resulted in a toolkit developed based on the country's experiences. The toolkit serves as a guideline in helping developing countries to successfully implement e-government initiatives; and gain a comprehensive understanding of e-government [28]. 
E-government development framework in Singapore involves three implementation stages: initiation, infusion and customization [16]. The framework is based on edemocracy framework developed by Watson and Mundy [32].

Mundy and Musa propose a framework for state level e-government in Nigeria. The framework emphasises policy formulation, implementation, and IT education and citizen sensitization through channels such as mobiles, cyber cafes, kiosks etc. [20]. In the next section, we provide a comparison of these nine guidelines.

Table 1. A review of e-government guidelines along their main activities

\begin{tabular}{|c|c|}
\hline $\begin{array}{l}\text { Framework / } \\
\text { guideline }\end{array}$ & Main activities as suggested in the Framework/Guideline \\
\hline $\begin{array}{l}\text { EGOV* framework } \\
\text { for developing coun- } \\
\text { tries [9] }\end{array}$ & $\begin{array}{l}\text { Examine e-government readiness } \\
\text { Formulate e-government vision and strategy } \\
\text { Develop e-government program } \\
\text { Build human capacity } \\
\text { Build institutional capacity } \\
\text { Build research capacity }\end{array}$ \\
\hline $\begin{array}{l}\text { Framework for } \\
\text { e-government [12] }\end{array}$ & $\begin{array}{l}\text { Examine e-government readiness } \\
\text { Identify and prioritize themes } \\
\text { Develop e-government program } \\
\text { Apply to target groups and implement }\end{array}$ \\
\hline $\begin{array}{l}\text { Guideline for de- } \\
\text { signing country } \\
\text { wide } \\
\text { e-government } \\
\text { strategy (for devel- } \\
\text { oping countries) [5] }\end{array}$ & $\begin{array}{l}\text { Formulate a strategy and implementation plan } \\
\text { Examine e-government readiness } \\
\text { Determine implementation approach (bottom up vs. top down) } \\
\text { Implement pilot projects } \\
\text { Build institutional capacity ( public private partnership) } \\
\text { Develop supporting frameworks (legal, economic) } \\
\text { Formulate a reform strategy (incremental change vs. big bang) } \\
\text { Evaluate projects } \\
\text { Determine risk factors }\end{array}$ \\
\hline $\begin{array}{l}\text { Strategic } \\
\text { framework for } \\
\text { e-government [23] }\end{array}$ & $\begin{array}{l}\text { Formulate e-government vision } \\
\text { Outline strategic objectives } \\
\text { Determine the users } \\
\text { Determine delivery models (G2G, G2C, G2B, G2E, G2N) } \\
\text { Outline guiding principles (one-stop, packaged services etc.) } \\
\text { Determine delivery channels (Web, in-person, phone etc.) } \\
\text { Identify priority areas (service delivery, internal efficiency etc.) } \\
\text { Outline major initiatives (government portal, taxation system etc.) } \\
\text { Develop infrastructure } \\
\text { Develop supporting frameworks (organization, legal, interoperability) } \\
\text { Outline implementation guidelines (reusability, e-signature etc.) }\end{array}$ \\
\hline $\begin{array}{l}\text { Government to } \\
\text { e-government } \\
\text { transition [8] }\end{array}$ & $\begin{array}{l}\text { Formulate e-government vision } \\
\text { Implement initial e-government technologies } \\
\text { Formulate an alignment plan of government and e-government strategies } \\
\text { Align government and e-government strategies and systems } \\
\text { Transform government processes and systems }\end{array}$ \\
\hline $\begin{array}{l}\text { UNESCO } \\
\text { e-government } \\
\text { action plan (for } \\
\text { developing } \\
\text { countries) [30] }\end{array}$ & $\begin{array}{l}\text { Formulate e-government vision } \\
\text { Raise e-government awareness } \\
\text { Build human capacity } \\
\text { Build institutional capacity (establish an apex organization and partnership) } \\
\text { Develop infrastructure } \\
\text { Develop supporting frameworks (laws, policies) } \\
\text { Prioritize and implement pilot projects } \\
\end{array}$ \\
\hline
\end{tabular}




\begin{tabular}{|c|c|c|}
\hline $\begin{array}{l}\text { Framework for } \\
\text { Nigeria } \\
\text { e-government } \\
\text { development (for } \\
\text { developing coun- } \\
\text { tries) [20] }\end{array}$ & \multicolumn{2}{|c|}{$\begin{array}{l}\text { Formulate e-government policy } \\
\text { Publish information online with partial citizen participation } \\
\text { Establish interaction among government, businesses and citizens via website with } \\
\text { partial citizen participation } \\
\text { Establish transaction of government services via website with partial citizen } \\
\text { participation } \\
\text { Set up e-government portal with partial citizen participation } \\
\text { Establish full citizen participation at all government levels }\end{array}$} \\
\hline \multirow{3}{*}{$\begin{array}{l}\text { E-government } \\
\text { Action Plan: lessons } \\
\text { from republic of } \\
\text { Korea (for develop- } \\
\text { ing countries) [28] }\end{array}$} & $\begin{array}{l}\text { Pre- } \\
\text { implementation }\end{array}$ & $\begin{array}{l}\text { Establish leadership and raise awareness } \\
\text { Build institutional capacity (public private partnership etc.) } \\
\text { Examine e-government readiness } \\
\text { Benchmark other leading practices }\end{array}$ \\
\hline & Implementation & $\begin{array}{l}\text { Formulate e-government vision and goals } \\
\text { Develop implementation roadmap } \\
\text { Determine implementation approach (bottom up vs. top down) } \\
\text { Build capacity (human, financial, technical, legal etc.) } \\
\text { Develop e-government system }\end{array}$ \\
\hline & $\begin{array}{l}\text { Post- } \\
\text { implementation }\end{array}$ & $\begin{array}{l}\text { Evaluate and monitor projects } \\
\text { Perform system operation and maintenance } \\
\text { Manage information and technological resources } \\
\text { Manage system utilization and review e-government outcomes }\end{array}$ \\
\hline \multirow{3}{*}{$\begin{array}{l}\text { E-government } \\
\text { development in } \\
\text { Singapore (for } \\
\text { developing coun- } \\
\text { tries) [32] }\end{array}$} & Initiation stage & $\begin{array}{l}\text { Formulate e-government vision } \\
\text { Publish information online } \\
\text { Set up e-government portal }\end{array}$ \\
\hline & Infusion stage & $\begin{array}{l}\text { Formulate action plan } \\
\text { Outline guiding principles } \\
\text { Build capacity (human, financial, technical, legal etc.) } \\
\text { Develop infrastructure } \\
\text { Raise awareness }\end{array}$ \\
\hline & $\begin{array}{l}\text { Customization } \\
\text { stage }\end{array}$ & $\begin{array}{l}\text { Integrate services for collaboration among government agencies } \\
\text { Incorporate CRM in e-services } \\
\text { Monitoring e-government projects }\end{array}$ \\
\hline
\end{tabular}

\section{Comparison of Existing Guidelines}

The comparison is performed using clustering analysis. Jain et al. define clustering as "exploratory data analysis technique" and "unsupervised classification of patterns into groups (clusters) based on their similarities" [15]. The authors outline stages of clustering technique illustrated in Fig. 1 consisting of feature selection, similarity characterization and grouping to form clusters.

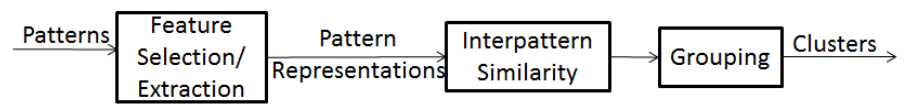

Fig. 1. Stages in clustering according to Jain et al [15]

Based on this clustering analysis model, the feature selection criteria for the activities of guidelines/frameworks were based on the output/purpose of activities. Furthermore for each activity in the guidelines, keywords such as vision, strategy, implementation plan, roadmap, evaluation etc. were analysed. Subsequently, identified keywords and activities 
with similar output/purpose were grouped into clusters as illustrated in Table 2. The first column of the table names the clusters of activities, followed by number of occurrences in guidelines and reference to the literature, in which the activities were mentioned. The last column of the table indicates the number of activities occurring in guidelines identified for developing countries.

The comparison in Table 2 illustrates that clusters such as formulation of e-government vision, formulation of e-government policy/strategy, examination of e-readiness, and implementation of e-government (programs, pilot projects, system, portals) are observed most among the guidelines $(\geq 4)$. Other activities are observed only in one or two guidelines such as benchmarking practices from other countries, establishing political leadership, establishing citizen participation, determining risk factors, determining delivery models and/or channels, e-government integration and/or alignment, and e-government transformation.

Table 2. Comparison of guidelines for designing e-government systems

\begin{tabular}{|l|l|l|}
\hline Cluster of activities & $\begin{array}{l}\text { No. of occurrences of } \\
\text { activities and reference to } \\
\text { frameworks / guidel. }\end{array}$ & $\begin{array}{l}\text { Of which f. } \\
\text { developing } \\
\text { countries }\end{array}$ \\
\hline Formulate of e-government vision & 6 from [8, 9, 16, 23, 28,30] & 4 \\
\hline Formulate of e-government policy/ strategy & 4 from [5, 9, 20, 23] & 3 \\
\hline Examine e-readiness & 4 from [5, 9, 12, 28] & 3 \\
\hline Raise awareness & 3 from [16, 28, 30] & 3 \\
\hline Benchmark practices from other countries & 1 from [28] & 1 \\
\hline $\begin{array}{l}\text { Formulate implementation plan, roadmap, approach, } \\
\text { guidelines and/or principles }\end{array}$ & 5 from [5, 8, 16, 23, 28] & 3 \\
\hline $\begin{array}{l}\text { Implement e-government (programs, pilot projects, } \\
\text { system, portals) }\end{array}$ & $\begin{array}{l}9 \text { from[5, 8, 9, 12, 16, 20, } \\
23,28,30]\end{array}$ & 6 \\
\hline Develop infrastructure & 3 from [16,23,30] & 2 \\
\hline Prioritize projects and/or themes & 3 from [12, 23, 30] & 1 \\
\hline $\begin{array}{l}\text { Build capacity (human, institutional, technical } \\
\text { financial, research) }\end{array}$ & 6 from [5, 9, 16, 23, 28,30] & 5 \\
\hline $\begin{array}{l}\text { Develop supporting frameworks and/or standards } \\
\text { (legal, economic, organization, interoperability) }\end{array}$ & 3 from [5, 23, 30] & 2 \\
\hline Establish political leadership & 1 from [28] & 1 \\
\hline Establish citizen participation & 1 from [20] & 1 \\
\hline Evaluate, monitor and/or maintain projects & 3 from [5,16, 28] & 3 \\
\hline Determine risk factors & 1 from [5] & 1 \\
\hline Determine delivery models and/or channels & 1 from [23] & - \\
\hline E-government integration and/or alignment & 2 from [8, 16] & 1 \\
\hline E-government transformation & 1 from [8] & - \\
\hline
\end{tabular}

Another observation drawn from the comparison is the difference in scope of activities among the guidelines. Some guidelines are based on experiences from specific countries such as Republic of Korea [28], Singapore [16] and Nigeria [20], others 
build on contexts of developing countries [5, 9, 30], and yet others have no specific context $[8,12,23]$. Activities such as formulation of e-government vision, formulation of e-government policy/strategy, examining e-readiness, implementation of egovernment (programs, pilot projects, system, portals), formulation of implementation plan, roadmap, approach, guidelines and/or principles span across all scopes of guidelines. Furthermore most guidelines do not provide clear relations among the different activities suggested, which may result in unclear objectives of activities and hence difficulties to measure and to ensure benefits and value-adds along the process. The findings further reveal a lack of comprehensive reference frameworks to guide countries in designing and managing e-government initiatives.

Before we present our framework, insights into the challenges for designing egovernment systems in developing countries are discussed in the next section.

\section{Challenges for Designing E-Government Systems in Developing Countries}

Implementation of e-government systems signifies interrelations between the government and citizens (G2C), government and businesses (and non-profit organizations) (G2B, G2NPO), intergovernmental agencies and departments (G2G) and government and employees (G2E). Designing and sustaining e-government systems requires rigorous consideration of political, economic, technological, social, cultural and legal status of the country. Such prerequisites impose significant design challenges, which have to be faced by developing countries. Most developing countries suffer from emerging economies, high corruption, political instabilities, unclear legal structures and diverse social and cultural norms, which greatly contribute to the challenges of designing e-government systems. Table 3 sums up challenges and barriers in designing e-government systems in developing countries as documented in literature.

Table 3. Challenges for designing e-government systems in developing countries

\begin{tabular}{|l|l|}
\hline \multicolumn{1}{|c|}{ Challenge } & \multicolumn{1}{c|}{ Source (s) } \\
\hline Political \& organizational leadership & {$[4,10,11,21,24,27,30]$} \\
\hline Formulation of strategy and policy & {$[4,21,24]$} \\
\hline Prioritization of initiatives & {$[25]$} \\
\hline Availability of financial resources & {$[10,11,25,30]$} \\
\hline Public-private partnership & {$[4,21]$} \\
\hline ICT literacy of public sector employees & {$[4,10,11,21,24,25,27,30,31]$} \\
\hline ICT literacy of end user & {$[2,21,25,30]$} \\
\hline Formulation of legal framework & {$[4,21,24,27]$} \\
\hline Formulation of security and privacy guidelines & {$[2,10,24]$} \\
\hline Cultural factors & {$[4,10,11,21,27,30]$} \\
\hline Infrastructure & {$[2,4,10,11,21,24,27,31]$} \\
\hline Integration of backend processes & {$[10,31]$} \\
\hline Awareness of opportunities & {$[24,25,30]$} \\
\hline
\end{tabular}


The challenges outlined above emphasize the necessity to vigilant planning and implementation of e-government system in developing countries. Furthermore, the challenges emphasize the need for evaluating e-government systems for measuring their benefits and public value-add towards sustainable economic and social developments and the knowledge society. The next section therefore proposes a comprehensive framework for e-government systems design, while accounting for the challenges in designing e-government systems in developing countries and introducing a step of evaluating public value-add and benefits of e-government initiatives.

\section{$5 \quad$ Consolidating Guidelines into a Comprehensive Strategic Framework for Designing E-Government Systems}

In section 3, existing guidelines for designing e-government systems were compared using clustering analysis technique. Among other observations previously discussed, eight guidelines indicate vision and policy/strategy as entry points to embark on egovernment initiatives followed by implementation plans and execution where most activities in the guidelines involve different stages of executing the plans. However the relationship between the stages is unclear and, therefore, it remains difficult to evaluate and measure the value-add.

In this regard, we herewith compose a strategic framework emphasizing that public value-add is considered in e-government initiatives. The framework provides a clear entry point and a clear relationship among different activities involved in developing e-government systems, and in turn providing policy makers and e-government coordinators the ability to better measure the value-add and resulting benefits of initiatives.

The proposed framework embarks on previous literature: In their work to study the innovation of e-participation in the European regions, Scherer et al. outline a concept, which describes the relationship between strategies, programmes and projects. The authors describe a strategy as "a long term plan of action", which is implemented through programs bound by duration and budget. The programs are then implemented through projects [26]. Wimmer outlines "e-government application layers" consisting of three dimensions: political and strategic, implementation and operation. The first dimension is comprised of formulating a vision and strategies, whereas the latter is supported by concepts such as Business Process Re-engineering (BPR) and New Public Management (NPM). Initiatives are then formulated, in which the strategies are assessed through allocated financial and operative resources. If agreed upon, then the initiatives are implemented in the next dimension through projects. The last dimension describes application of ICT in public administration. The results and experiences of the process are reviewed through feedback from the applications to the projects, initiatives, strategies and vision, hence, an iterative cycle with feedback on the success of ICT applications towards the stated vision and strategies [34].

On the basis of the guidelines outlined in sections 2 and 3, as well as of the models proposed in [26] and [34], figure 2 presents the strategic framework for e-government design. 


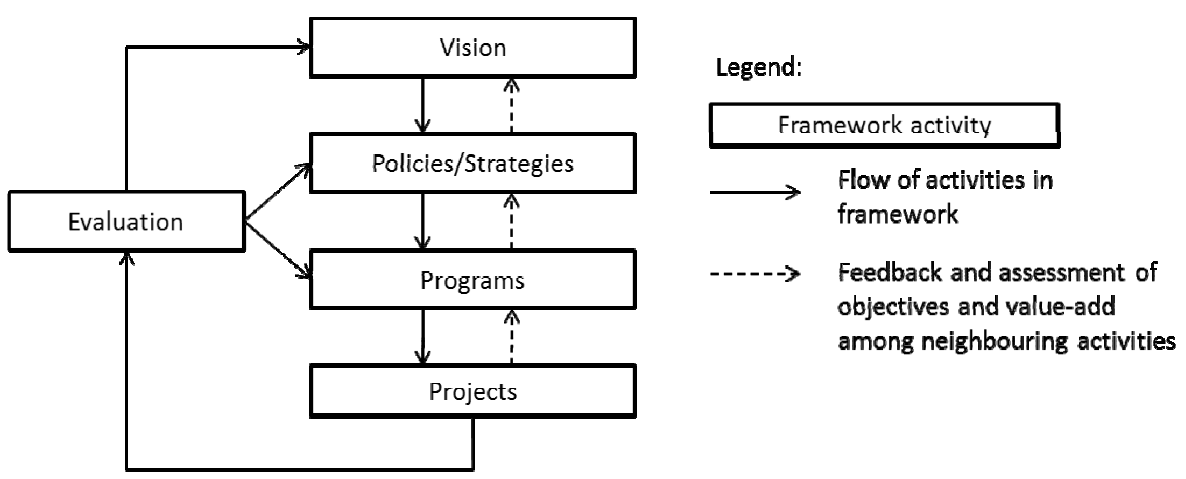

Fig. 2. Strategic framework for e-government systems design

The overall nature of the framework is iterative, because for each evaluated project, reflection is necessary to map the whole development process with the vision. The feedback between two neighbouring activities is introduced to ensure evaluation in each activity, and not only along the whole process cycle. The subsequent subsections outline each of the activities of the framework, which reflect the clusters of activities emerging from the analysis outlined in Table 2 and the challenges for designing e-government systems in developing countries outlined in Table 3 above.

\subsection{Vision}

A vision is a long term view of where an organization wants to be and acts as an overall guiding principle in an organization hence bringing forth the importance of articulating vision statements before starting an endeavour. Vision statements provide the basis of achieving certain objectives. In e-government the statements define the state of government after a certain period of time. Each country has its own vision which reflects national priorities, the economic and political context of a country [28, 30]. Furthermore, formulation of vision statements should involve stakeholders such as governments, citizens and businesses [9, 30]. Vision statements should also include e-government goals and directions which are shared among stakeholders and all government levels [18].

Formulating a vision statement is the first step through which the policies and strategies of e-government are derived. Many vision statements in this regard include phrases such as citizen centric, recognition as a leader in e-government implementation, responsive, innovative, easily accessible, transparent and consumer-based governments. Vision statements also provide a basis for governments to measure the value of implementing e-government systems through goals foreseen in the statements.

\subsection{Policies/Strategies}

Policies and strategies describe a set of commitments to implement actions in order to achieve the vision statements. They define detailed goals and objectives for 
implementation which reflect the overall vision. Also defined here are the political, economic, social, cultural, technological and legal prerequisites necessary for implementation. Risks and risk management are also defined in policies and strategies. Application of ICT in public sectors poses several risks such as organizational, technological, skill, infrastructure, financial and legal risks [1, 32]. Therefore these should be addressed while setting policies and strategies. Other aspects for implementation such as change management, public-private partnership, organizational and business architectures are also defined in this stage.

Nation-wide e-government policies and strategies are important so as to form an alignment of implementation from the national to local levels. The significance of such alignment is to ensure re-usability and interoperability among solutions, traceability, monitoring and evaluation of resources across all levels. Examples of policies and strategies are formulations of e-government agencies and units to coordinate nation-wide e-government initiatives, formulation of government portal and provision of electronic services and formulation of e-government framework.

\subsection{Programs}

E-government policies and strategies are implemented through a set of defined programs [26, 34]. Such programs must reflect the goals and objectives described in policies and strategies. A program stems implementation approaches adopted in projects in the next step. Acknowledging the wide scope of government transformation through ICT and limitation of resources, it is important to formulate a series of programs which oversee the implementation of projects.

The first purpose is the ability to prioritize implementation of projects. Several e-government projects working towards dependent objectives and goals in certain program provide the ability to prioritize them. The programs ensure that the projects are prioritized according to available financial and human resources, benefits and impact. The second purpose is careful planning of resources. Due to scarce resources available in developing countries, a series of programs ensures that for each program there is definitive amount of resources dedicated, and risks from one program can be transferred to subsequent programs. The third purpose is the high level of traceability among projects in programs. Management of programs becomes more viable as compared to scattered implementation projects working towards diverse objectives and goals. An example in this regard is a program that oversees the resources required for constructing e-government portal and coordination of services offered in the portal. The program determines financial and human resources, cost, and design of services in the portal such as designs according to life events.

\subsection{Projects}

In this step the programs are implemented in projects. Each project is implemented towards certain detailed objectives and goals reflected in a program [26]. And such 
objectives must also reflect the overall national e-government vision. The most preferable implementation approach in projects is through pilot projects with considerable scope. The significance of this approach is to minimize risks, measure benefits of projects in early stages, assess the demand of initiative from stakeholders and learn lessons for future projects $[5,7,29,30]$. Adopting concepts and practices from Information Systems field, implementation of projects consists of activities such as requirements gathering and analysis, design approaches, development, implementation and monitoring and evaluation. Other activities relevant to e-government projects are also suggested in the literature such as global and local surveys on similar projects to obtain lessons and best practices, training of staff and research to gain state-of-the art solutions and implementation approaches [5]. Examples of projects are the provision of electronic services such as birth registration, electronic allocation of land, computerization of departments and ministries.

\subsection{Evaluation}

In order to best measure the value-add, progress and if the results of the project concur to the overall vision, objectives and goals of policies and strategies as well as of programs, evaluation is an important aspect. The purpose of evaluation in this guideline is to provide the basis for measuring the value of e-government projects to the governments as providers of services; and citizens, businesses and non-governmental organizations as receivers of services. Evaluation of e-government projects is also significant to assess the status of development, perform SWOT analysis as a learning basis [17, 29] and improve policy making for future implementation [19]. Furthermore evaluation provides the basis for more effective policies and strategies by assessing customers' needs and their expectations [31].

Several evaluation methods exist in the literature in which authors describe the indicators and factors for evaluation. Implementation of e-government initiatives from setting of vision statements to implementation in projects is country-specific, characterized by distinctive political, economic, social, cultural and technological status. Therefore the indicators for measuring the values and benefits of e-government initiatives should reflect the vision of e-government and the status of the country along the mentioned characteristics. Also supported by [2], the authors propose an evaluation framework covering economic, social and technical aspects. The aspects are elaborated further into performance, accessibility, cost-saving, openness, trust and usefulness of e-government initiatives. Other indicators used in evaluation are such as back office and front office (supply and demand), and impact of e-government to government and its customers [17]. Syamsuddin proposes an evaluation framework for developing countries [29] based on the ITPOSMO model (Information, Technology, Processes, Objectives and values, Staffing and skills, Management systems and structures and other resources) developed by Heeks [13]. Heeks uses the model to describe the gap existing between the status of the country implementing e-government and design of e-government initiatives in which he described the gap as highly contributing to the failure of most e-government initiatives in developing countries [14]. 


\section{Lessons Learnt and Recommendations}

The development of the strategic framework proposed in this paper relied on the comparison of nine guidelines found in literature. Along the study, several lessons and recommendations of best practices to design e-government systems emerged, which are summed up in this section.

The first recommendation is preliminary research on innovative solutions and best practices. The role of research for successful e-government is highly noted in the literature $[9,35]$. The e-government field has evolved tremendously in the past decade and the level of maturity is enormously different between developed and developing countries, and also among developing countries as the UN survey 2012 evidences [31]. Such gap provides an opportunity for countries to leverage and exchange knowledge on innovative solutions and practices.

Designing national e-government frameworks should consider political, economic, social, cultural and technological status of the country. Heeks reasons that most e-government projects in developing countries fail due to the gap between the design of e-government systems and the reality [13]. Many developing countries implement e-government systems designs from developed countries without taking into consideration the differences in historical and cultural aspects, infrastructure, people, economic and government structures [6].

In order to provide practical experiences and to facilitate successful e-government adoption in developing countries, governments should encourage more publications from their experiences illustrating frameworks, challenges, failures, risks and proposed remedies. Such collaboration will reduce failures, encourage application of innovative solutions among governments and enhance empirical learning.

Designing systems, which clearly reflect on users' needs, is also crucial for successful systems. It will ensure usability and successful adoption of the systems. Users' needs reflect factors such as design of e-services (such as life events designs), channels of services (offline and online), languages and prioritization of projects which contribute to significant values to societies.

Finally, the framework proposed in this paper is useful for e-government coordinators and policy makers in design of e-government. The framework recommends political, social, cultural, economic and technological prerequisites, and risks to be analysed at an early stage of designing e-government systems. Formulation of the vision and objectives of policies/strategies should reflect the status of the country along the mentioned prerequisites. This will enhance an early discovery of potential challenges; therefore development of proper remedies along programs, projects and evaluation are crucial. Furthermore, it will enable proper planning of resources as governments will be able to design and prioritize e-government initiatives based on available human and financial resources.

\section{Conclusion}

Developing countries have embarked in implementing e-government systems as developed countries. Faced with many challenges, designing valuable e-government initiatives 
require careful planning and management. Many guidelines for designing e-government systems are proposed in the literature, whereas some of the guidelines are developed in the context of developing countries and others not. However there is still lack of a comprehensive guideline that will enable developing countries to design e-government systems in very challengeable environments whilst generating value from the initiatives.

The paper also investigates challenges for designing e-government systems in developing countries to better understand issues documented in the literature based on practice and reviews. Developing countries are faced with many political, social, cultural, economic and technical challenges such as poor support of political leadership, ICT illiteracy, cultural resistance, limited financial resources and lack of infrastructure. On this basis, a strategic framework for e-government systems design in developing countries is suggested. The framework consists of five activities: vision, policies/strategies, programs, projects and evaluation. The vision determines the desired state of government after a certain period of time. The policies/strategies describe a set of political commitments with detailed goals and objectives that reflect the vision. The programs determine strategies and actions to be implemented in projects with a commitment of financial resources. The projects implement the goals described in the programs. The last activity is evaluation which enables governments to ensure that the projects generate desired values, measure the state of e-government and better plan for future policies/strategies.

The paper concludes with lessons learnt from the development process of the framework and recommendations for designing e-government systems in developing countries. To conclude, further research on reviewing existing guidelines and practical experiences of applying the framework is needed and is planned as next steps.

\section{References}

1. Evangelidis, A., Akomode, J., Taleb-Bendiab, A., Taylor, M.: Risk Assessment \& Success Factors for e-Government in a UK Establishment. In: Traunmüller, R., Lenk, K. (eds.) EGOV 2002. LNCS, vol. 2456, pp. 395-402. Springer, Heidelberg (2002)

2. Alshawi, S., Alahmary, A., Alalwany, H.: E-government Evaluation Factors: Citizen's Perspective. Information Technology for Development - e-Government Initiatives in the Developing World: Challenges and Opportunities 15(3), 193-208 (2009)

3. Basu, S.: E - government and developing countries: an overview. International Review of Law, Computers \& Technology 18(1), 109-132 (2004)

4. Belachew, M.: E-government initiatives in Ethiopia. In: Davies, J., Janowski, T. (eds.) Proceedings of the 4th International Conference on Theory and Practice of Electronic Governance (ICEGOV 2010), pp. 49-54. ACM, New York (2010)

5. Bhatnagar, S.: E-Government: From Vision to Implementation - A Practical Guide With Case Studies. SAGE publications, India (2004)

6. Chen, Y.N., Chen, H.M., Huang, W., Ching, R.K.H.: E-government strategies in developed and developing countries: An implementation framework and case study. Journal of Global Information Management (JGIM) 14(1), 23-46 (2006)

7. Dada, D.: The failure of e-government in developing countries: A literature review. The Electronic Journal of Information Systems in Developing Countries 26 (2006) 
8. Davison, R.M., Wagner, C., Ma, L.C.K.: From government to e-government: a transition model. Information Technology \& People 18(3), 280-299 (2005)

9. Dshusupova, Z., Janowski, T., Ojo, A., Estevez, E.: Sustaining Electronic Governance Programs in Developing Countries. In: Klun, M., Decman, M., Jukić, T. (eds.) Proceedings of the 11th European Conference on eGovernment (ECEG 2011), pp. 203-212. Academic Publishing Limited, Reading (2011)

10. Ebrahim, Z., Irani, Z.: E-government adoption: architecture and barriers. Business Process Management Journal 11(5), 589-611 (2005)

11. Furuholt, B., Wahid, F.: E-government Challenges and the Role of Political Leadership in Indonesia: the Case of Sragen. In: Proceedings of the 41st Annual Hawaii International Conference on System Sciences (HICSS 2008), p. 411. IEEE Computer Society, Washington (2008)

12. Gichoya, D.: Factors affecting the successful implementation of ICT projects in government. The Electronic Journal of e-Government 3(4), 175-184 (2005)

13. Heeks, R.: Information Systems and Developing Countries: Failure, Success and Local Improvisations. The Information Society 18(2), 101-112 (2002)

14. Heeks, R.: Most e-Government-for-Development Projects Fail: How Can Risks be reduced? iGovernment Working Paper Series, no. 14 (2003)

15. Jain, A.K., Murty, M.N., Flynn, P.J.: Data Clustering: A Review. ACM Computing Surveys (CSUR) 31(3), 264-323 (1999)

16. Ke, W., Wei, K.K.: Successful e-government in Singapore. Communications of the ACM 47(6), 95-99 (2004)

17. Kunstelj, M., Vintar, M.: Evaluating the progress of e-government development: A critical analysis. Information Polity 9, 131-148 (2004)

18. Lam, W.: Barriers to e-government integration. Journal of Enterprise Information Management 18(5), 511-530 (2005)

19. Lenk, K., Traunmüller, R.: Electronic Government: Where Are We Heading? In: Traunmüller, R., Lenk, K. (eds.) EGOV 2002. LNCS, vol. 2456, pp. 1-9. Springer, Heidelberg (2002)

20. Mundy, D., Musa, B.: Towards a Framework for eGovernment Development in Nigeria. Electronic Journal of E-government 8, 148-166 (2010)

21. Ndou, V.: E-government for developing countries: opportunities and challenges. The Electronic Journal of Information Systems in Developing Countries 18(1), 1-24 (2004)

22. OECD: The Case for E-Government: Excerpts from the OECD Report "The EGovernment Imperative". OECD Journal on Budgeting 3(1), 61-131 (2003)

23. Rabaiah, A., Vandijck, E.: A Strategic Framework of e-Government: Generic and Best Practice. Electronic Journal of e-Government 7(3), 241-258 (2009)

24. Rashid, N., Rahman, S.: An Investigation into Critical Determinants of e-Government Implementation in the Context of a Developing Nation. In: Andersen, K.N., Francesconi, E., Grönlund, Å., van Engers, T.M. (eds.) EGOVIS 2010. LNCS, vol. 6267, pp. 9-21. Springer, Heidelberg (2010)

25. Sæbø, Ø.: E-government in Tanzania: Current Status and Future Challenges. In: Scholl, H.J., Janssen, M., Wimmer, M.A., Moe, C.E., Flak, L.S. (eds.) EGOV 2012. LNCS, vol. 7443, pp. 198-209. Springer, Heidelberg (2012)

26. Scherer, S., Schneider, C., Wimmer, M.A.: Studying eParticipation in Government Innovation Programmes: Lessons from a Survey. In: Hampe, F., Swatman, P.M.C., Gricar, J., Pucihar, A., Lenart, G. (eds.) 21st Bled eConference on eCollaboration: Overcoming Boundaries through Multi-Channel Interaction, pp. 15-18 (2008) 
27. Schuppan, T.: E-Government in developing countries: Experiences from sub-Saharan Africa. Government Information Quarterly 26(1), 118-127 (2009)

28. Song, H.: E-Government in Developing Countries: Lessons Learned from Republic of Korea. Communication and Information (CI), Bangkok (2006),

http: / /www2 . unescobkk . org/elib/publications / 083 /egovernment.pdf (accessed January 31, 2013)

29. Syamsuddin, I.: Evaluation of e-government initiatives in developing countries: an ITPOSMO approach. International Research Journal of Applied and Basic Sciences 2(12), 439-446 (2011)

30. UNESCO: E-government toolkit for developing countries. UNESCO, New Delhi (2005), http://unesdoc. unesco.org/images/0013/001394/139418e.pdf (accessed January 31, 2013)

31. United Nations: United Nations E-Government Survey 2012: E-Government for the People (2012),

http: / / unpan1.un.org/intradoc/groups/public/documents / un/unp an048065.pdf (accessed January 11, 2013)

32. Walser, K., Kühn, A., Riedl, R.: Risk management in e-government from the perspective of IT governance. In: Chun, A.S., Sandoval, R., Regan, P. (eds.) Proceedings of the 10th Annual International Conference on Digital Government Research: Social Networks: Making Connections between Citizens, Data and Government (dg.o 2009), pp. 315-316. Digital Government Society of North America (2009)

33. Watson, R.T., Mundy, B.: A strategic perspective of electronic democracy. Communications of the ACM 44(1), 27-30 (2001)

34. Wimmer, M.A.: A European Perspective Towards Online One-stop Government: The eGOV Project. Electronic Commerce Research and Applications 1(1), 92-103 (2002)

35. Wimmer, M.A.: The role of research in successful e-government implementation. In: EGovernment Guide Germany. Strategies, Solutions and Efficiency, pp. 79-87. Fraunhofer IRB Verlag, Stuttgart (2007) 